\title{
Production of commercially important enzymes from Bacillus licheniformis KIBGE- IB3 using date fruit wastes as substrate
}

\author{
Fatima Aslam¹, Asma Ansari², Afsheen Aman², Granaz Baloch', Gissed Nisar', Abdul Hameed Baloch ${ }^{3}$ and \\ Haneef Ur Rehman ${ }^{1 *}$
}

\begin{abstract}
Background: Pakistan is one of the top five date fruit-producing countries and produced more than 30\% wastes in picking, packing, storage, and commercialization stages. The date fruit wastes are usually considered inedible for humans and only used for livestock feed. In current research, Bacillus licheniformis KIBGE-IB3 was screened for pectinase, xylanase, cellulase, and amylase production using date fruit wastes as substrate through solid state fermentation.

Results: The B. licheniformis KIBGE-IB3 produced higher concentration of pectinase using date fruit wastes as substrate as compared to amylase, cellulase, and xylanase. B. licheniformis KIBGE-IB3 produced maximum pectinase using $5.0 \mathrm{~g} / \mathrm{dl}$ date fruit wastes and $0.5 \mathrm{~g} / \mathrm{dl}$ yeast extract. B. licheniformis KIBGE-IB3 required $\mathrm{pH} 7.0,37^{\circ} \mathrm{C}$ incubation temperature, and $72 \mathrm{~h}$ incubation period for maximum production of pectinase.
\end{abstract}

Conclusion: It has been concluded that date fruit waste is a good source of biomass and can be utilized for the commercial production of pectinase.

Keywords: Bacillus licheniformis, Date fruit wastes, Enzymes, Solid state fermentation

\section{Background}

Enzymes due to its catalytic properties have been used for various industrial processes including food, diagnosis, pharmaceutical, and textile. Currently more than 4000 enzymes are identified and 200 are used for industrial preparations. Majority of enzymes are carbohydratebased due to its natural availability for living organisms as biomass. Microbial enzymes are usually preferred for commercial applications due to technical easiness to obtain, economical feasibility, and easy product recovery and optimization. The cost of microbial enzymes depend on the substrates used to induce the enzyme production during fermentation [1].

B. subtilis, B. stearothermophillus, B. licheniformis, and B. amyloliquefaciens are reported extensively as industrial

\footnotetext{
*Correspondence: haneef.baloch@uot.edu.pk

'Department of Natural and Basic Sciences, University of Turbat, Turbat 92600, Pakistan

Full list of author information is available at the end of the article
}

enzyme producer of enzymes due to generally recognized as safe [2-4]. Solid state fermentation technology (SSF) using biological wastes as substrate for production enzymes by microbial strains much more cost effective technique as compared to submerged fermentation (SmF) technology $[4,5]$.

Date palms are cultivated in many region countries of the Middle East and the Central Asia, and its fruits have been used as stable food. Approximately more than 120 million date palm trees are cultivated on 800,000 ha in more than 30 countries globally [6, 7]. Pakistan is one of the top five date fruit-producing countries. More than $30 \%$ wastes were generated in picking, packing, storage, and commercialization stages of date fruit preparation. It has been reported that the date palm trees produced 4.5 million tons wastes across the world [8]. These wastes mostly are left in agricultural lands and burned [9].

In the current research, date fruit wastes were screened as substrate for the production of commercially 
important enzymes such as pectinase, amylase, cellulase, and xylanase through solid state fermentation (SSF). Furthermore, the production parameters of SSF were optimized for maximum biosynthesis of pectinase using date fruit wastes.

\section{Methods}

\section{Collection of date fruit wastes}

Date palm fruit wastes were collected from the local farms. The collected date palm fruit waste was kept in a large tray and cleaned, and the dust and dirt particles were removed. Date palm fruit waste was air-dried, covered with a muslin cloth, and kept at room temperature for $48 \mathrm{~h}$.

\section{Bacterial strains}

The bacterial strain Bacillus licheniformis KIBGE-IB3 was obtained from the culture bank of Industrial Biotechnology Section, Dr. A. Q. Khan Institute of Biotechnology and Genetic Engineering (KIBGE) University of Karachi, which was previously isolated from indigenous source [10].

\section{Solid state fermentation}

Solid state fermentation was done by fermentation of $B$. lichemiformis KIBGE-IB3 using a 250-ml Erlenmeyer flask containing $5 \%$ date fruit wastes as substrate in a 250-ml flask (sterilized at $120^{\circ} \mathrm{C} / 40 \mathrm{~min}$ ) and inoculated with $10 \mathrm{ml}$ aliqouts of $B$. lichemiformis KIBGE-IB3 in medium containing peptone $0.025 \%$, yeast extract $0.015 \%, \mathrm{MgSO}_{4} 0.001 \%$, and $\mathrm{K}_{2} \mathrm{HPO}_{4} 0.0005 \%$ at $\mathrm{pH} 7.0$. The fermentation was carried out at $37^{\circ} \mathrm{C}$ for $72 \mathrm{~h}$, and after that, the solid fermented material was mixed with $30 \mathrm{ml}$ distilled water and stirred for $30 \mathrm{~min}$. Then, the mixture was centrifuged $4000 \mathrm{rpm}$ for $20 \mathrm{~min}$ and the supernatant was used for crude enzyme.

\section{Screening of date fruit wastes for pectinase, xylanase, cellulase, and amylase production}

Bacillus licheniformis KIBGE-IB3 was screened for pectinase, xylanase, cellulase, and amylase production using date fruit wastes as substrate. Four different media with different compositions (Table 1) were used specifically for amylase, pectinase, xylanase, and cellulase production.
Equal size of inoculums was used in each media for each specific enzyme production and fermented at $\mathrm{pH} 7.0$ and $37^{\circ} \mathrm{C}$ for $72 \mathrm{~h}$.

\section{Analysis of physical and chemical parameters of SSF for pectinase biosynthesis}

The chemical and physical parameters of SSF including medium composition, temperature, $\mathrm{pH}$, and incubation period were optimized for pectinase production. The concentration effect of date fruit wastes, nitrogen source, fermentation period, temperature, and $\mathrm{pH}$ were analyzed by fermenting the $B$. licheniformis KIBGE-IB3 through one variable at time approach.

\section{Enzyme assays}

The enzyme assays of pectinase, xylanase, cellulase, and amylase were performed by incubation of crude enzyme with $1 \%$ substrate specific for each enzyme (pectin, xylan, cellulose, and starch) for a defined time period, and after that, the concentration of the end product (galacturonic acid, xylose, and glucose) produced was measured by DNS method. The unit definition of enzymes is "quantity of enzyme needed to produce one $\mu \mathrm{mol}$ of product per minutes under defined physical and chemical conditions".

\section{Results}

Using of date fruit wastes for the production of enzymes

Bacillus licheniformis KIBGE-IB3 were inoculated in four different media specific for each enzyme production with the addition of $5 \%$ date fruit wastes in each medium. It was observed that Bacillus licheniformis KIBGE-IB3 produced pectinase, xylanase, amylase, and cellulase using date fruit wastes but pectinase production was higher as compared to the others enzymes (Table 2).

\section{Analysis of physical and chemical parameters of solid state fermentation}

The fermentation parameters of SSF technology was optimized for pectinase production by $B$. licheniformis KIBGE-IB3 using one variable at time approach.

Table 1 Media composition for various enzyme production

\begin{tabular}{lllll}
\hline Chemicals & Medium-1 (pectinase) $(\mathrm{g} / 100 \mathrm{ml})$ & Medium-2 (cellulase) (g/100ml) & Medium-3 (xylanase) & Medium-4 (amylase) \\
\hline Date fruit wastes & $5 \mathrm{~g}$ & $5 \mathrm{~g}$ & $5 \mathrm{~g}$ & $5 \mathrm{~g}$ \\
Peptone & $0.025 \mathrm{~g}$ & $0.025 \mathrm{~g}$ & $0.025 \mathrm{~g}$ & $0.025 \mathrm{~g}$ \\
Yeast extract & $0.015 \mathrm{~g}$ & $0.015 \mathrm{~g}$ & $0.015 \mathrm{~g}$ & $0.015 \mathrm{~g}$ \\
$\mathrm{MgSO}_{4}$ & $0.001 \mathrm{~g}$ & $0.001 \mathrm{~g}$ & $0.001 \mathrm{~g}$ & $0.001 \mathrm{~g}$ \\
$\mathrm{~K}_{2} \mathrm{HPO}_{4}$ & $0.0005 \mathrm{~g}$ & $0.0005 \mathrm{~g}$ & $0.0005 \mathrm{~g}$ & $0.0005 \mathrm{~g}$ \\
& Pectin $0.05 \mathrm{~g}$ & $\mathrm{CMC} 0.05 \mathrm{~g}$ & Xylan $0.05 \mathrm{~g}$ & Starch $0.05 \mathrm{~g}$ \\
\hline
\end{tabular}


Table 2 Screening of date fruit wastes for the production of pectinase, xylanase, cellulase, and amylase by Bacillus licheniformis KIBGE-IB3

\begin{tabular}{lll}
\hline S. No. & Enzymes & Enzyme activity $(\mathrm{U} / \mathrm{ml} / \mathrm{min})$ \\
\hline $\mathbf{1}$ & Amylase & 23,383 \\
$\mathbf{2}$ & Xylanase & 1341 \\
$\mathbf{3}$ & Cellulase & 821 \\
$\mathbf{4}$ & Pectinase & 30,600 \\
\hline
\end{tabular}

\section{Influence of date fruit waste concentration on pectinase production}

The effect of date fruit waste concentration on the production of pectinase from $B$. licheniformis KIBGE-IB3 was analyzed using various concentrations of date fruit wastes ranging from 0 to $10 \%$ in fermentation medium. The production of pectinase from B. licheniformis KIBGE-IB3 was increased by increasing the date fruit waste concentration, and maximum production was achieved in the medium containing $5.0 \%$ of date fruit wastes (Fig. 1). Further increase of date fruits beyond 5.0 $\mathrm{g} / \mathrm{dl}$ concentration decreased the pectinase production. No production of pectinase was seen at $0 \%$ of date fruit wastes.

\section{Influence of nitrogen sources on pectinase production}

The effect of nitrogen source on the production of pectinase from Bacillus licheniformis KIBGE-IB3 was analyzed by using a different type of nitrogen source in fermentation media, separately. It was observed that $\mathrm{Ba}$ cillus licheniformis KIBGE-IB3 produced higher pectinase in yeast extract containing fermentation medium as compared to the other nitrogen sources (Fig. 2). The inorganic nitrogen sources reduced the pectinase production up to $70-50 \%$ with the comparison of yeast extract.

\section{Influence of incubation time on pectinase production} The influence of incubation period on Bacillus licheniformis KIBGE-IB3 on the production of pectinase was monitored by fermenting the Bacillus licheniformis KIBGE-IB3 for different incubation times (24-120 h). Bacillus licheniformis KIBGE-IB3 started pectinase synthesis within $24 \mathrm{~h}$, and the highest synthesis was obtained after $72 \mathrm{~h}$ of incubation (Fig. 3). The synthesis of pectinase was decreased when the fermentation period was increased to $120 \mathrm{~h}$, and almost 15 to $50 \%$ pectinase synthesis was declined by Bacillus licheniformis KIBGEIB3 at 96 and $120 \mathrm{~h}$, respectively.

\section{Influence of temperature on pectinase production}

The effect of incubation temperature on the production of pectinase from $B$. licheniformis KIBGE-IB3 was investigated by incubating the bacterial strains in different incubation temperatures. The biosynthesis of pectinase from Bacillus licheniformis KIBGE-IB3 was improved when the temperature was increased from 20 to $30{ }^{\circ} \mathrm{C}$, and the highest biosynthesis of pectinase was obtained when the bacterial strain is incubated at $37{ }^{\circ} \mathrm{C}$ (Fig. 4). The pectinase biosynthesis was reduced to 36 to $10 \%$ when the temperature was increased to 40 and $50{ }^{\circ} \mathrm{C}$, respectively.

\section{Influence of $\mathrm{pH}$ on pectinase production}

Bacillus licheniformis KIBGE-IB3 was inoculated in different media with different $\mathrm{pH}(5.0-9.0)$ at constant temperature and date fruit waste concentration for $72 \mathrm{~h}$ incubation. Bacillus licheniformis KIBGE-IB3 biosynthesized pectinase at a broad $\mathrm{pH}$ range (5-8) (Fig. 5). The pectinase biosynthesis was gradually increased by increasing the initial $\mathrm{pH}$ of fermentation medium and biosynthesized higher pectinase at $\mathrm{pH}$ 7.0. The variation of initial $\mathrm{pH}$ of fermentation medium beyond 7.0 either

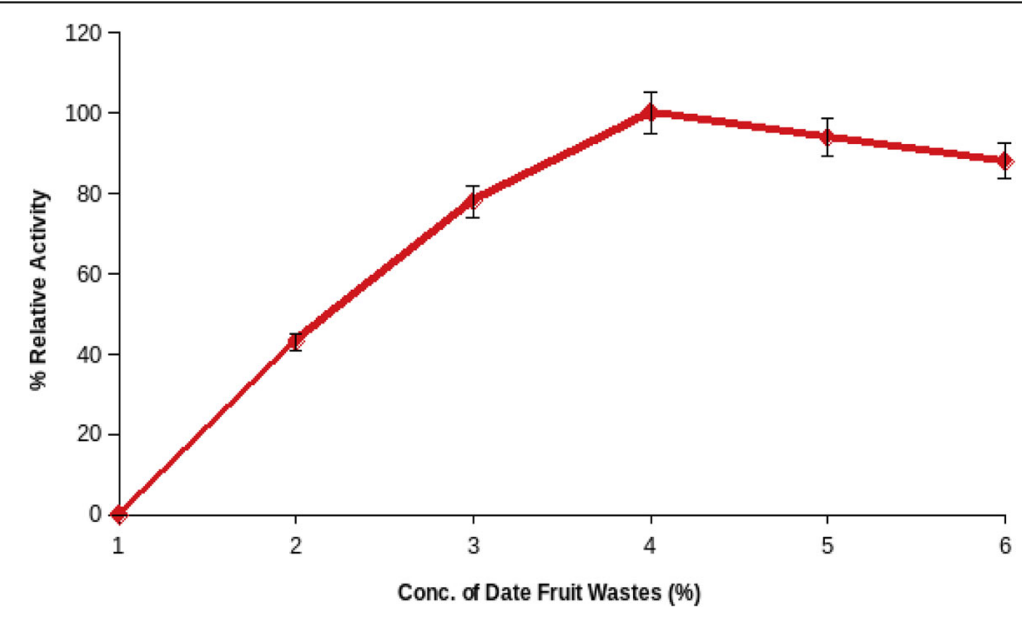

Fig. 1 The influence of date fruit waste concentration on pectinase production by $B$. licheniformis KIBGE-IB3 (means \pm S.E., $n=6$ ) 


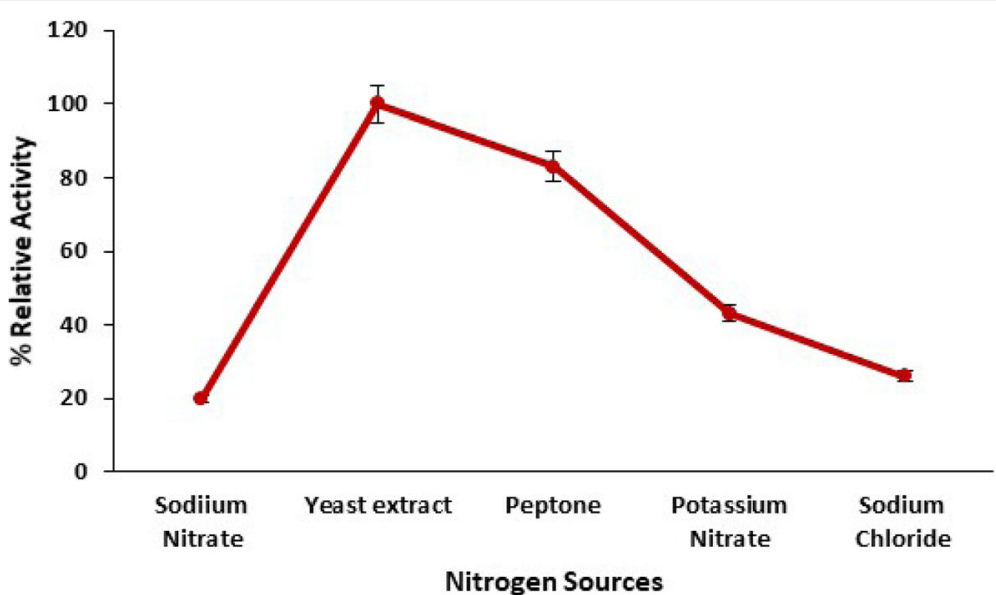

Fig. 2 The influence of nitrogen sources on pectinase production by B. licheniformis KIBGE-IB3 using date fruit wastes as substrate (means \pm S.E. $n=6)$

towards acidic (6.0 to 5.0) or alkaline (8.0 to 9.0) side reduced the pectinase biosynthesis.

\section{Discussions}

The Bacillus licheniformis KIBGE-IB3 collected from KIBGE microbial bank was screened for pectinase, xylanase, amylase, and cellulase production using date fruit wastes as substrate by the SSF method. The Bacillus licheniformis KIBGE-IB3 produced higher pectinase as compared to cellulase, amylase, and xylanase using date fruit wastes. The higher production of pectinase by $B$. licheniformis KIBGE-IB3 using date fruit wastes may be due to the composition wastes, microbial sources, or genetic composition of bacterial strains. The utilization of date fruit wastes is for the production of value-added products by microbial species [11].
Fermentation technology is influenced by various growth factors such as composition of fermentation medium, temperature, $\mathrm{pH}$, and incubation period. These physical and chemical factors are prime important for commercial production of enzymes, and various protocols have been suggested for enzyme production by microbial species [12,13]. We used one variable at a time approach used for pectinase production by $B$. licheniformis KIBGE-IB3.

The B. licheniformis KIBGE-IB3 produced maximum pectinase using $5.0 \mathrm{~g} / \mathrm{dl}$ date fruit wastes as substrate by solid state fermentation technology. Further increase of date fruit waste concentration reduced the pectinase production due to substrate-based inhibition and reduction of cell multiplication. The type of substrate and its concentration are very important for the manufacturing of microbial enzymes. It does not only work as a carbon

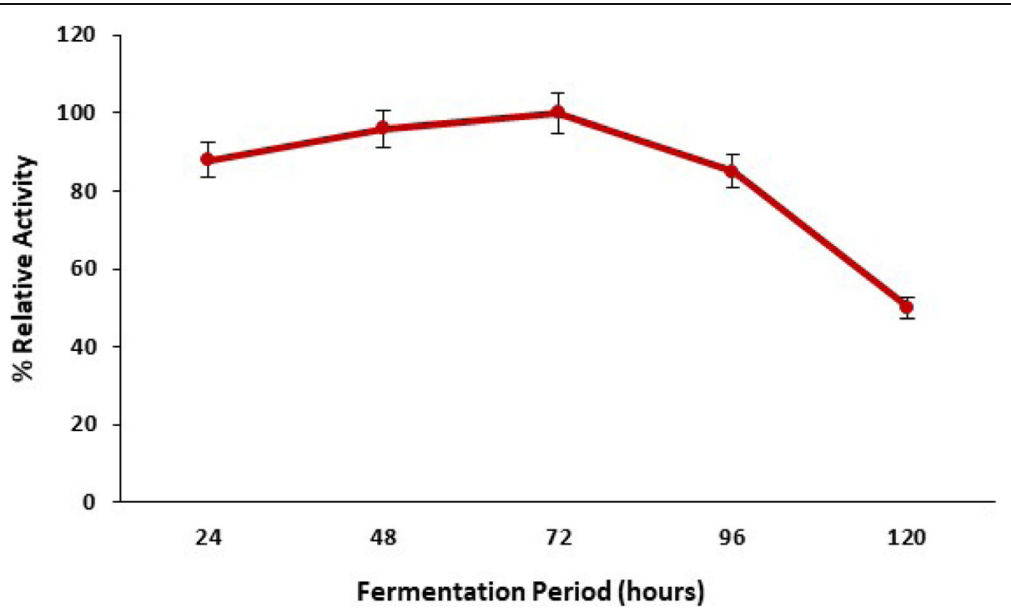

Fig. 3 The influence of fermentation period on pectinase production by B. licheniformis KIBGE-IB3 using date fruit wastes as substrate (means \pm S.E., $n=6$ ) 


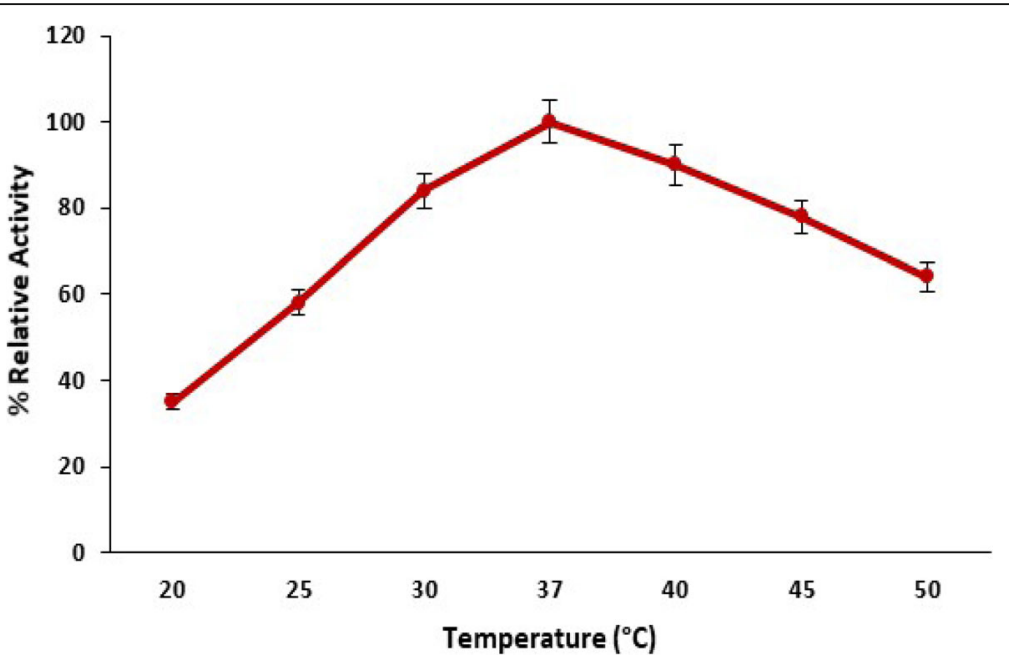

Fig. 4 The influence of temperature on pectinase production by B. licheniformis KIBGE-IB3 using date fruit wastes as substrate (means \pm S.E., $n=6$ )

source but also acts as inducer for specific enzyme production [14]. The production of pectinase was inducible in nature, and B. licheniformis KIBGE-IB3 did not produce pectinase without having substrate as date fruit wastes. The yeast extract with its complex composition supports the pectinase production, and B. licheniformis KIBGE-IB3 produced higher pectinase using yeast extract as a nitrogen source. The yeast extract contained various metal ions, proteins, vitamins, and other organic compounds which may fulfill the physiological needs of B. licheniformis KIBGE-IB3 for pectinase production. The yeast extract as a nitrogen source also induced the pectinase production from fungal species [15]. The microbial strains usually produced higher enzymes using complex organic nitrogen sources as compared to inorganic nitrogen sources [16]. The addition of yeast extract, peptone, and ammonium chloride in fermentation medium increased the pectinase production from
Bacillus sp. DT7, while glycine, urea, and ammonium nitrate inhibited the pectinase production [17]. Peptone has been also found as a good organic nitrogen source for pectinase production form Bacillus firmus-I-10104 [12]. Bacillus licheniformis KIBGE-IB3 biosynthesized maximum pectinase after $72 \mathrm{~h}$ fermentation. Bacillus sphacricus (MTCC 7542) also produced pectinase. Similar findings were reported earlier regarding the synthesis of pectinase from [18]. The culture conditions and composition of media are important to maintain the microbial growth, and Bacillus licheniformis KIBGE-IB3 sustained a $\log$ phase within 24 to $72 \mathrm{~h}$ in terms of pectinase production. The reduction of pectinase production after increasing the fermentation time beyond $72 \mathrm{~h}$ of incubation might be due to exhaustion of substrate concentration in fermentation medium and the accumulation of toxic byproduct. It has been reported that the Bacillus firmus-I-10104 produced maximum pectinase after an incubation of $96 \mathrm{~h}$ [12].

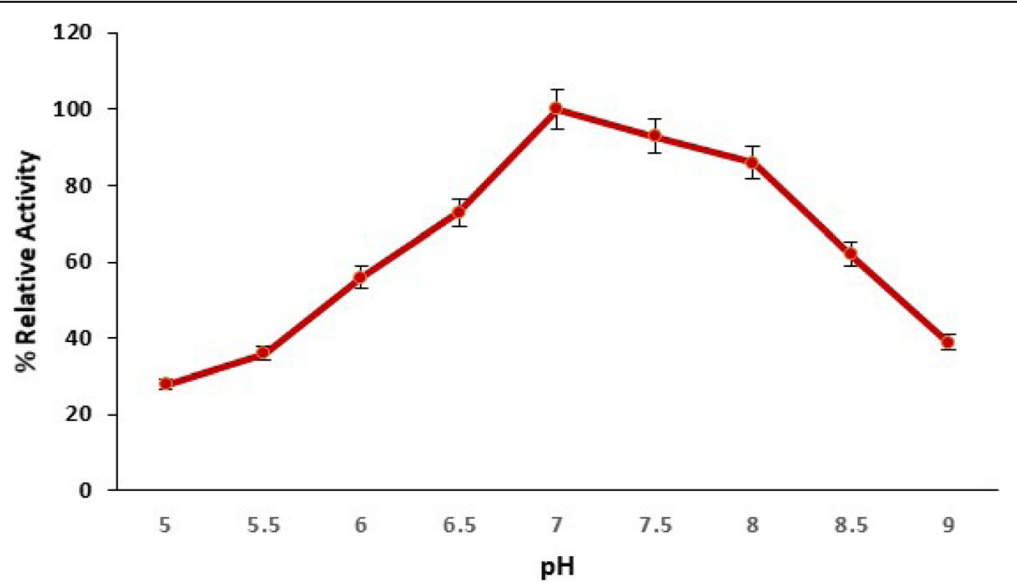

Fig. 5 The influence of $\mathrm{pH}$ on pectinase production by B. licheniformis KIBGE-IB3 using date fruit wastes as substrate $($ means \pm S.E., $n=6$ ) 
Temperature is a very important factor for microbial enzyme production, and the biosynthesis of pectinase was improved by increasing the temperature from 20 to $37^{\circ} \mathrm{C}$. B. licheniformis KIBGE-IB3 biosynthesized higher pectinase at $37{ }^{\circ} \mathrm{C}$. The biosynthesis of pectinase from bacterial strains was usually occurred within $37^{\circ} \mathrm{C}$ [19]. Bacillus licheniformis KIBGE-IB3 synthesized pectinase at a higher temperature as compared to other microbial species which usually synthesized pectinase at $30{ }^{\circ} \mathrm{C}[18$, 20]. The Bacillus licheniformis KIBGE-IB3 is mesophilic in behavior for pectinase biosynthesis.

The $\mathrm{pH}$ has a significant role for biosynthesis of enzymes [21]. The Bacillus species were usually synthesis enzymes from neutral to alkaline $\mathrm{pH}$ ranging from $\mathrm{pH}$ 7.0 to $\mathrm{pH} 9.0$ [22-24]. Bacillus licheniformis KIBGE-IB3 biosynthesized pectinase at a broad $\mathrm{pH}$ range (5-8) and synthesized higher pectinase at $\mathrm{pH}$ 7.0. Bacillus licheniformis KIBGE-IB3 is neutrophilic in nature for pectinase production. The bacterial strains usually have optimum $\mathrm{pH}$ around neutral or alkaline for pectinase production, and fungi produce pectinase from neutral to acidic $\mathrm{pH}$ range. Bacillus sp. DT7 showed similar results and maintained maximum pectinolytic activity at neutral $\mathrm{pH}$ [25]. Aspergillus niger produced maximum pectinase at $\mathrm{pH}$ 6.5 [26], while Aspergillus fumigatus biosynthesized high pectinase at $\mathrm{pH} 4.0$ [27].

\section{Conclusion}

In the current study, Bacillus licheniformis KIBGE-IB3 was screened for the synthesis of amylase, xylanase, cellulase, and pectinase using date fruit wastes as substrate by solid state fermentation. Bacillus licheniformis KIBGE-IB3 produced higher pectinase using date fruit wastes as substrate as compared to other xylanase, cellulase, and amylase. The physical and chemical parameters of $B$. licheniformis of solid state fermentation were optimized for maximum pectinase production. B. licheniformis synthesized maximum pectinase using $5.0 \mathrm{~g} / \mathrm{dl}$ date fruit wastes and $0.5 \mathrm{~g} / \mathrm{dl}$ yeast extract. The production of pectinase reached maximum by keeping the fermentation of B. licheniformis KIBGE-IB3 at pH 7.0 and $37{ }^{\circ} \mathrm{C}$ for $72 \mathrm{~h}$ of incubation. B. licheniformis showed practicable properties for pectinase production using date fruit wastes. Further studies are needed to analyze the commercial feasibility of utilization of date fruit wastes for synthesis of enzymes as well as for the production of other value-added products.

\section{Acknowledgments}

The authors acknowledged the support of the University of Turbat and Higher Education Commission Pakistan for providing infrastructure for conducting the research and also acknowledged the support of Dr. A. Q. Khan Institute of Biotechnology and Genetic Engineering University of Karachi for supporting us in the experimental works.

\section{Authors' contributions}

All authors read and approved the manuscript for submission. AF designed the concept and performed the experiment and initially drafted the research article. AA analyzed and interpreted and supervised some of the experimental works. AA supported the designing of the experimental works and the interpretation of results. GB contributed in the experimental works and drafting of the research article. GN contributed in the sample collection and microbial fermentations. AHB interpreted the results and revised the draft. HUR designed the concept and supervised the total experimental works and drafted the final version of the article to be published and corresponded with the publisher.

\section{Funding}

There was no funding for this study.

Availability of data and materials

Available on request.

Ethics approval and consent to participate

Not applicable.

Consent for publication

Not applicable.

\section{Competing interests}

The authors declare no competing interest.

\section{Author details}

${ }^{1}$ Department of Natural and Basic Sciences, University of Turbat, Turbat 92600, Pakistan. ${ }^{2}$ Dr. A. Q. Khan Institute of Biotechnology and Genetic Engineering (KIBGE), University of Karachi, Karachi, Pakistan. ${ }^{3}$ Faculty of Agriculture, Lasbela University of Agriculture, Water and Marine Sciences (LAWMS), Uthal, Pakistan.

Received: 9 May 2020 Accepted: 13 August 2020

Published online: 31 August 2020

\section{References}

1. Gurung N, Ray S, Bose S, Rai V (2013) A broader view: microbial enzymes and their relevance in industries, medicine, and beyond. Biomed Res Int 2013

2. Gombert AK, Pinto AL, Castilho LR, Freire DM (1999) Lipase production by Penicillium restrictum in solid-state fermentation using babassu oil cake as substrate. Process Biochem 35(1-2):85-90

3. Smits JP, Rinzema A, Tramper J, Schlösser EE, Knol W (1996) Accurate determination of process variables in a solid-state fermentation system. Process Biochem 31(7):669-678

4. Vijayabaskar P, Jayalakshmi D, Shankar T (2012) Amylase production by moderately halophilic Bacillus cereus in solid state fermentation. Afr J Microbiol Res 6(23):4918-4926

5. Soni SK, Kaur A, Gupta JK (2003) A solid state fermentation based bacterial a-amylase and fungal glucoamylase system and its suitability for the hydrolysis of wheat starch. Process Biochem 39(2):185-192

6. Al-Kaabi K, Al-Khanbashi A, Hammami A (2005) Date palm fibers as polymeric matrix reinforcement: DPF/polyester composite properties. Polym Compos 26(5):604-613

7. El-Juhany LI (2010) Degradation of date palm trees and date production in Arab countries: causes and potential rehabilitation. Aust J Basic Appl Sci 4(8):3998-4010

8. Barreveld, W. H. (1993). Date palm products. FAO.

9. Bashah M (1996) Date variety in the Kingdom of Saudi Arabia. King Abdulaziz Univ. Guidance booklet palms and dates. King Abdulaziz Univ. Press, Riyadh, pp 1225-1319

10. Ghani M, Ansari A, Aman A, Zohra RR, Siddiqui NN, Qader SAU (2013) Isolation and characterization of different strains of Bacillus licheniformis for the production of commercially significant enzymes. Pak J Pharm Sci 26(4): 691-697

11. Chandrasekaran M, Bahkali AH (2013) Valorization of date palm (Phoenix dactylifera) fruit processing by-products and wastes using bioprocess technology—review. Saudi J Biol Sci 20(2):105-120 
12. Bayoumi RA, Yassin HM, Swelim MA, Abdel-All EZ (2008) Production of bacterial pectinase $(s)$ from agro-industrial wastes under solid state fermentation conditions. J Appl Sci Res 4:1708-1721

13. Soares MMCN, Da Silva R, Gomes E (1999) Screening of bacterial strains for pectinolytic activity: characterization of the polygalacturonase produced by Bacillus sp. Rev Microbiol 30:299-303

14. Kaur S, Guptha V (2017) Production of pectinolytic enzymes pectinase and pectin lyase by bacillus subtilis SAV-21 in solid state fermentation. Ann microbial 67:333-342

15. Aguilar G, Trejo T, Garcia J, Huitron G (1991) Influence of pH on endo-and exo-pectinase production by Aspergillus sp. CH-Y-1043. Can J Microbiol 37: 912-917

16. Vivek R, Rajasekharan M, Ravichandran R, Sriganesh K, Vaitheeswaran V (2010) Pectinase production from orange peels extract and dried orange peel solid as substrate using Aspergillus niger. Int J Biotechnol Biochem 6: 445-453

17. Kashyap DR, Soni SK, Tewari R (2003) Enhanced production of pectinase by Bacillus sp. DT7 using solid state fermentation. Bioresour Technol 88:251-254

18. Jayani RS, Shukla SK, Gupta R (2010) Screening of bacterial strains for polygalacturonase activity: its production by Bacillus sphaericus (MTCC 7542) Enzyme Res 2010. https://doi.org/10.4061/2010/306785

19. Soriano M, Diaz P, Pastor FIJ (2005) Pectinolytic systems of two aerobic sporogenous bacterial strains with high activity on pectin. Curr Microbiol 50: 114-118

20. Galiotou-Panayotou M, Kapantai M, Kalantzi O (1997) Growth conditions of Aspergillus sp. ATHUM-3482 for polygalacturonase production. Appl Microbiol Biotechnol 47:425-429

21. Murad HA, Refaea RI, Aly EM (2011) Utilization of UF-permeate for production of $\beta$-galactosidase by lactic acid bacteria. Pol J Microbiol 2:139-144

22. Horikoshi K (1972) Production of alkaline enzymes by alkalophilic microorganisms. Part III. Alkaline pectinase of Bacillus No P-4-N. Agric Biol Chem 36:285-293

23. Kelly CT, Fogarty WM (1978) Production and properties of polygalacturonate lyase by an alkalophilic microorganism Bacillus sp. RK9. Can J Microbiol 24: 1164-1172

24. Kobayashi T, Koike K, Yoshimatsu T, Higaki N, Suzumatsu A, Ozawa T, Hatada Y, Ito S (1999) Purification and properties of a low-molecular weight, highalkaline pectate lyase from an alkaliphilic strain of Bacillus. Biosci Biotechnol Biochem 63:65-72

25. Kashyap DR, Chandra S, Kaul A, Tewari R (2000) Production, purification and characterization of pectinase from a Bacillus sp. DT7. World J Microbiol Biotechnol 16:277-282

26. Debing J, Peijun L, Stagnitti F, Xianzhe X, Li L (2006) Pectinase production by solid fermentation from Aspergillus niger by a new prescription experiment. Ecotoxicol Environ Saf 64:244-250

27. Phutela U, Dhuna V, Sandhu S, Chadha BS (2005) Pectinase and polygalacturonase production by thermophilic Aspergillus fumigatus isolated from decomposing orange peels. Braz J Microbiol 36:63-69

\section{Publisher's Note}

Springer Nature remains neutral with regard to jurisdictional claims in published maps and institutional affiliations.

\section{Submit your manuscript to a SpringerOpen ${ }^{\circ}$ journal and benefit from:}

- Convenient online submission

- Rigorous peer review

- Open access: articles freely available online

- High visibility within the field

- Retaining the copyright to your article

Submit your next manuscript at $\boldsymbol{\nabla}$ springeropen.com 